\title{
Adjuvant concentrations and uredospore densities on Phakopsora pachyrhizi infection efficiency in soybean
}

\author{
Tiago Zanatta, Erlei Melo Reis ${ }^{1}$ e Mateus Zanatta
}

Universidade de Passo Fundo, Faculdade de Agronomia e Medicina Veterinária, Passo Fundo, RS. ${ }^{1}$ Bolsista do CNPq

Autor para correspondência: Erlei Melo Reis (erleireis@ upf.br)

Data de chegada: 10/10/2010. Aceito para publicação em: 02/01/2012.

\section{ABSTRACT}

Zanatta, T.; Reis, E.M. Adjuvant concentrations and uredospore densities on Phakopsora pachyrhizi infection efficiency in soybean. Summa Phytopathologica, v.38, n.2, p.148-151, 2012.

Experiments were carried out in a growth chamber to evaluate the effect of spreader and uredospore concentrations on the efficiency of infection by Phakopsora pachyrhizi, the causal agent of Asian soybean rust. CD 214 RR soybean cultivar was inoculated with the following polyoxyethylene sorbitane monolaurate concentrations: $0,30,60,120,240,480$ and $960 \mu \mathrm{L} \mathrm{L}^{-1}$ water, as well as a fixed uredospore concentration of $2 \times 10^{4}$ spores. $\mathrm{mL}^{-1}$. In a second phase, the inoculum concentrations of $0,5 \times 10^{3}, 1 \times 10^{4}, 2 \times 10^{4}, 4 \times 10^{4}$,
$8 \times 10^{4}$ and $16 \times 10^{4}$ uredospores. $\mathrm{mL}^{-1}$ were evaluated, and the spreader concentration of $240 \mu \mathrm{L} . \mathrm{L}^{-1}$, selected in the previous experiment, was fixed. The spreader concentration of $240 \mu \mathrm{L} . \mathrm{L}^{-1}$ can be used in artificial inoculation studies, as well as up to $4 \times 10^{4}$ uredospores.mL${ }^{1}$. In this work, there was a correlation between uredia and lesion density. Thus, the use of lesion density is recommended to assess disease intensity for its accuracy and less time consuming. There was also a positive correlation between uredia and lesion density.

Additional keywords: Leaflet incidence, lesion density, Asian soybean rust, Glycine max.

\section{RESUMO}

Zanatta, T.; Reis, E.M. Efeito de concentração de adjuvante e da densidade de esporos sobre a eficiência de infecção de Phakopsora pachyrhizi em soja. Summa Phytopathologica, v.38, n.2, p.148-151, 2012.

Em experimentos realizadas em câmara de crescimento foi avaliado o efeito de concentrações de adjuvante e de concentrações de uredosporos sobre a eficiência da infecção de Phakopsora pachyrhizi, agente causal da ferrugem, em soja. O cultivar de soja CD 214 RR foi inoculado com as seguintes concentrações de polioxietileno sorbitano monolaurato: 0, 30, 60, 120, 240, 480 e $960 \mu \mathrm{L}^{-1}$ de água, com uma concentração fixa de $2 \times 10^{4}$ uredosporos.mL $L^{-1}$. Numa segunda fase, as concentrações de inóculo de $0,5 \times 10^{3}, 1 \times 10^{4}, 2 \times$
$10^{4}, 4 \times 10^{4}, 8 \times 10^{4}$ e $16 \times 10^{4}$ uredosporos. $\mathrm{mL}^{-1}$ foram avaliadas com a concentração do espalhante fixa em $240 \mu \mathrm{L}^{-1}$, selecionada do experimento anterior. A concentração de $240 \mu \mathrm{L}^{-1}$ pode ser utilizada em estudos de inoculação artificiais, bem como até 4 x $10^{4}$ uredospores. $\mathrm{mL}^{-1}$. Neste trabalho, houve uma relação entre a densidade de lesões com a densidade de urédias. O uso da densidade da lesões é sugerida para avaliar a intensidade da doença por sua precisão e com menos trabalho.

Palavras-chave adicionais: Folíolos, densidade de lesões, ferrugem asiática da soja, Glycine max.

Soybean [Glycine max (L.) Merrill] has become one of the most important economic crops worldwide. Expansion of cultivated acreage in the last growing seasons and the increased uses of its products and byproducts in human and animal feeding are among the main factors for this growth (5).

Soybean crop, from germination to harvest, is under continuous abiotic and biotic stresses of varied intensities (3). Among biotic stresses are those caused by nematodes, virus, bacteria and fungi (9).

Asian soybean rust (ASR) caused by the fungus Phakopsora pachyrhizi Sydow \& Sydow, since its first report in Brazil, has been considered a major disease for soybean crop (18), causing damages of up to $80 \%$.

Several studies have evaluated the effect of fungicides in ASR control and quantified the reaction of cultivars to this disease $(2,11$, $12,18)$. On the other hand, there was no report in the available literature related to the assessment of spreader concentrations and uredospore density on infection efficiency and intensity of ASR.

To determine the best spreader concentration and inoculum density on infection efficiency, it is important to optimize and standardize artificial inoculations in this pathosystem. Thus, the aim of this study is to assess the effects of spreader concentration and uredospore density on the infection efficiency and their reflex on ASR intensity.

\section{MATERIALAND METHODS}

Experiments were carried out in a growth chamber at the Faculty of Agronomy and Veterinary Medicine of University of Passo Fundo in Passo Fundo, Rio Grande do Sul State, Brazil, during the mounts of January to November of 2007. Experiments were repeated twice. 
Seeds of soybean cultivar CD 214 RR were sown at weekly intervals in polyethylene pots containing $2.0 \mathrm{~kg}$ substratum Tenomax (Ferticel) and kept in a growth chamber. Two seeds were laid in each $2.0 \mathrm{~cm}$-deep hole per pot. After seedling emergence, plants were thinned to five per pot. Plants were inoculated at V3 - V4 growing stages (13).

Uredospore suspension was primarily obtained from abundant uredia sporulation on leaves collected at the experimental field of University of Passo Fundo. Soybean leaflets were introduced into plastic containers ( $500 \mathrm{~mL}$ capacity plastic bottles) containing distilled water and the spreader polioxyethylene sorbitane monolaurate (PSM) (Tween 20 - Synth) at the concentration of $240 \mu \mathrm{L}^{-L^{-1}}$. The containers were hand shaken for uredospore release. Spore concentration was determined under a microscope by counting the spores present in a $10 \mu \mathrm{L}$ drop volume and repeated four times. Final concentrations were adjusted to the desired densities.

Inoculum was maintained throughout this work by weekly plant inoculation with $4 \times 10^{4}$ uredospores. $\mathrm{mL}^{-1}$ and spraying of the spore suspension onto healthy plants grown in another growth chamber. Inoculated plants were kept in the dark for 24 hours at $21^{\circ} \mathrm{C} \pm 2$ and leaf wetting period of 48 hours. After the inoculation period, plants were kept in the growth chamber under $14 \mathrm{~h}$ light $\mathrm{x} 10 \mathrm{~h}$ dark photoperiod at $23{ }^{\circ} \mathrm{C} \pm 2$.

Effects of spreader concentration on Phakopsora pachyrhizi infection efficiency

The following PSM concentrations were tested in the first experiment: 0, 30, 60, 120, 240, 480 and $960 \mu 1 . \mathrm{L}^{-1}$ distilled water and spore density of $2 \times 10^{4}$ uredospores. $\mathrm{mL}^{-1}$ water kept constant for each experiment.

Effects of Phakopsora pachyrhizi uredospore density on infection efficiency

In the second experiment, the following spore densities were tested: $0 ; 5,000 ; 10,000 ; 20,000 ; 40,000 ; 80,000$ and 160,000 uredospores.mL ${ }^{1}$ water and spreader concentration fixed to $240 \mu \mathrm{l} . \mathrm{L}^{-1}$ water, selected from the first experiment.

ASR intensity was quantified at 15 days after inoculation in 10 central leaflets randomly selected in each treatment. The number of lesions and uredia. $\mathrm{cm}^{-2}$ was quantified in a $0.9-\mathrm{cm}$ circle diameter marked in the two lateral central regions of each leaflet.

Experiments were conducted according to a complete randomized block design with four replicates. Data were subjected to analysis of variance and, when significant, to quadratic regression analysis. Experiments were repeated twice.

\section{RESULTS AND DISCUSSION}

Effects of spreader concentration on Phakopsora pachyrhizi infection efficiency

The uptake of water and chemical compounds by leaves is hampered by the presence of natural barriers in many plant species. The principal one is cuticle, which externally covers the surface of plants and has the function of protecting leaf tissues from dehydration (19). Similarly to lipophilic substances such as wax plates, cuticle has the capability of repelling water or impairing leaf wetting (14).

Spreaders or adjuvant substances reduce the superficial tension of water drops when sprayed onto the leaves, causing their flattening and increasing the surface contact and drop life duration. This mechanism, improving wetting and increasing the wetting period, may increase the efficiency of infection by pathogenic fungi, which require free water for infection (16).

As there was an increase in PSM adjuvant concentrations, there was also an increase in the number of uredia and ASR lesions in both experiments (Fig. $1 \mathrm{~A}$ and B).

The minimum disease intensity was obtained without the addition of spreader, whereas the maximum disease intensity was achieved by adding the highest spreader concentration, $960-\mu \mathrm{L} . \mathrm{L}^{-1}$ water of $P$. pachyrhizi uredospore suspension. Results showed similar trends in Experiments 1 and 2. Higher spreader concentrations also increased the number of ASR lesions and uredia, reaching a plateau at concentrations higher than $240 \mu \mathrm{l} . \mathrm{L}^{-1}$. Results of both experiments with CD 214 RR soybean cultivar showed that the use of spreader concentration of $240 \mu \mathrm{l} . \mathrm{L}^{-1}$ water improved the coverage of soybean leaflets and kept wetness for a minimum of 48 hours. Therefore, in future studies with this same cultivar or cultivars that have similar morphologic characteristics, the use of higher spreader concentrations is likely unnecessary.

Studies involving artificial inoculation of $B$. sorokiniana in wheat showed similar results (Zanatta et al., unpublished data). In this paper, the authors observed increased leaf spot intensity in consequence of the increased spreader concentration. The maximum intensity of leaf spot was obtained using $240-\mu l . \mathrm{L}^{-1}$ spreader in a conidial suspension in water.

Uredia and lesion density data were subjected to linear regression analysis (Figure $2 \mathrm{~A}$ and B). There was a significant correlation showing that the variables, lesion number and uredia, are mutually dependent. Therefore, independent of the assessed variable, results in both experiments were similar.

Reports about the effect of spreader concentrations on disease intensity were not found in the literature. As this fact is not well studied, the information generated in the present study can motivate the scientific community to develop projects aimed at increased infection efficiency in other pathosystems.

Effects of Phakopsora pachyrhizi uredospore density on infection efficiency.

Artificial plant inoculation with fungi is routinely practiced in plant pathology. In studies involving artificial inoculation, the inoculum concentration that leads to standardized and reproducible results must be identified (6). Numerous works determining the best inoculum concentration with other pathosystems have been published $(4,6$, 17).

Results show that there was an increase in disease intensity (uredia and lesions. $\mathrm{cm}^{-2}$ ) with increasing $P$. pachyrhizi uredospore concentration. The lower disease intensity was achieved with inoculations of 5,000 uredosporos. $\mathrm{mL}^{-1}$ water, generating an average of 96.2 and 25.9 uredia and lesions.cm ${ }^{-2}$ (Figure $3 \mathrm{~A}$ and B). Moreover, the disease intensity progressively increased until stability was obtained in inoculations with 80,000 uredosporos. $\mathrm{mL}^{-1}$, and the maximum disease intensity was achieved by inoculating 100,000 uredosporos. $\mathrm{mL}^{-1}$, generating an average 593.7 uredia and 183.9 lesions. $\mathrm{cm}^{-2}$. The difference in the number of uredia and lesions. $\mathrm{cm}^{-2}$ was $83.7 \%$ and $86.6 \%$, from the lowest to the highest concentration, respectively.

Other researchers working with distinct pathosystems $(4,6,17)$ have also demonstrated that the use of a higher inoculum density results in increased disease severity.

In both experiments, inoculation with uredospore concentrations above $80,000 . \mathrm{mL}^{-1}$ generated an excessive disease intensity, impairing 
the quantification and the determination of early leaf senescence.

On the other hand, for studies aimed at assessing the effect of fungicides on sub-phases of infection or the epidemiological processes of the disease, concentrations up to 40,000 uredosporos. $\mathrm{mL}^{-1}$ are recommended. Inoculations with the lowest concentrations generate individual lesions, facilitating their quantification.

Based on the present results, the highest concentrations may be useful in breeding programs, the aim of which is to select resistant genotypes.

There was a positive correlation between lesions and uredia densities and vice-versa (Figure $4 \mathrm{~A}$ and $\mathrm{B}$ ).

Besides the increase in the number of lesions, there was also a linear increase in the number of uredia. In the present pathosystem the quantification of the number of uredia demanded more time; thus, it is suggested that the disease be quantified by the number of lesions. $\mathrm{cm}^{-2}$, which yields similar results and has the advantage of being less time-consuming.

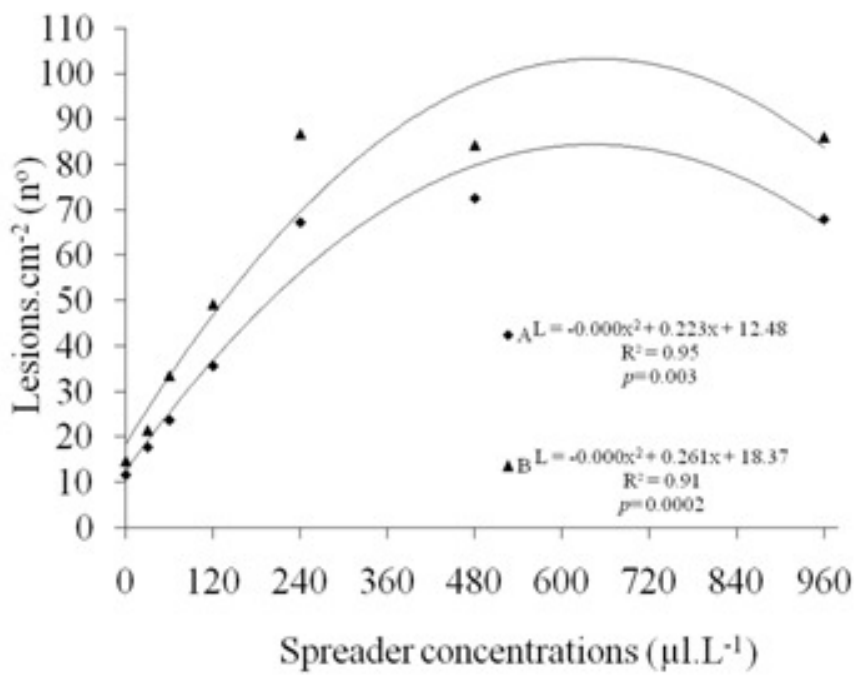

Figure 1. Relation between spreader concentrations and soybean rust lesion number.cm in soybean leaflets cultivar CD 214 RR. First experiment (A) and second experiment ( ). University of Passo Fundo, 2008.

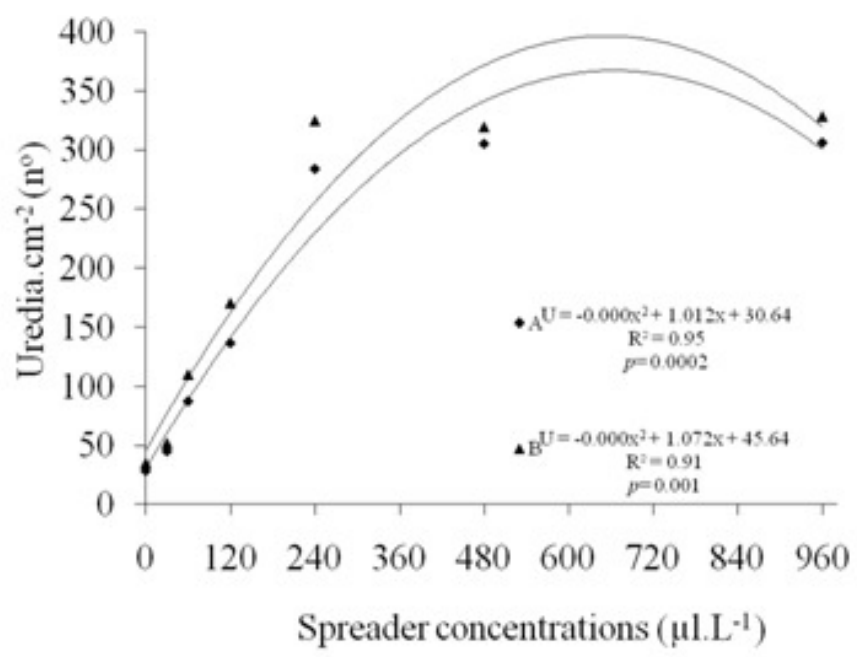

Figure 2. Relation between spreader concentrations and soybean rust uredia number. $\mathrm{cm}^{2}$ in soybean leaflets cultivar CD 214 RR. First experiment $(\boldsymbol{\Delta})$ and second experiment $(\diamond)$. University of Passo Fundo, 2008.

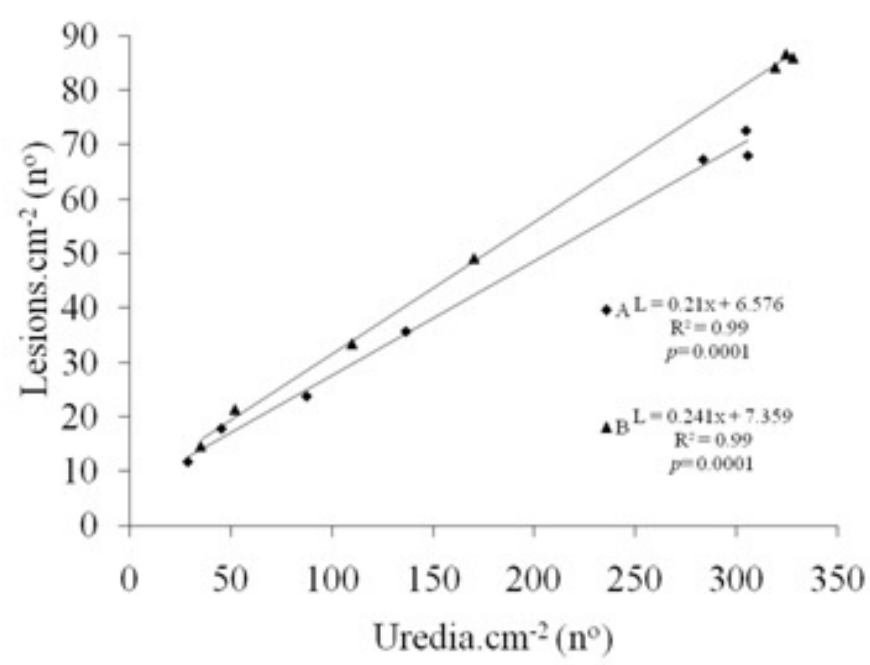

Figure 3. Relation between soybean rust uredia density (lesion number. $\mathrm{cm}^{-2}$ ) and lesion density (number. $\mathrm{cm}^{-2}$ ) in soybean leaflets of cultivar CD 214 RR. First experiment $(\boldsymbol{\Delta})$ and second experiment $(\diamond)$. University of Passo Fundo, 2008.

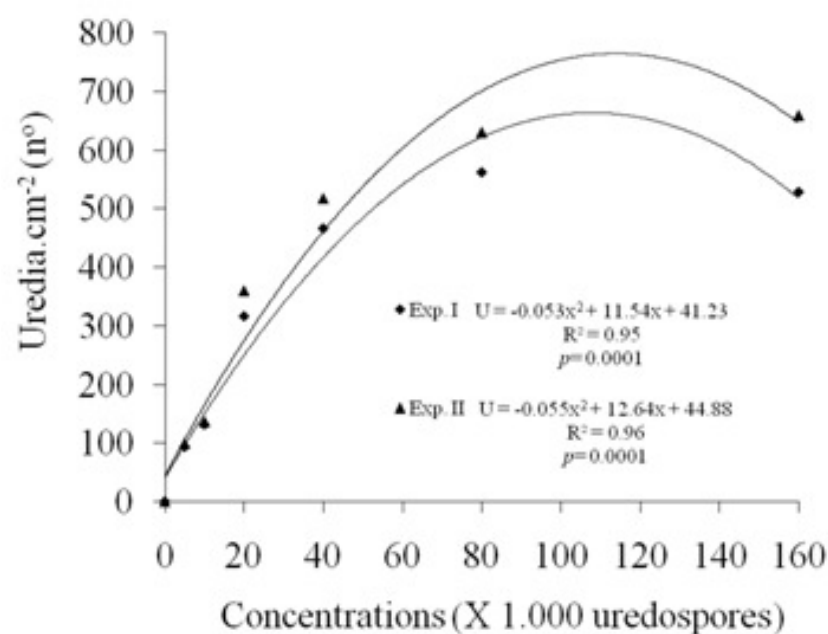

Figure 4. Relation between Phakopsora pachyrhizi urediospores and uredia density (lesions number. $\mathrm{cm}^{-2}$ ) in soybean leaflets of cultivar CD $214 \mathrm{RR}$. First experiment $(\boldsymbol{\Delta})$ and second experiment $(\boldsymbol{)})$. University of Passo Fundo, 2008.

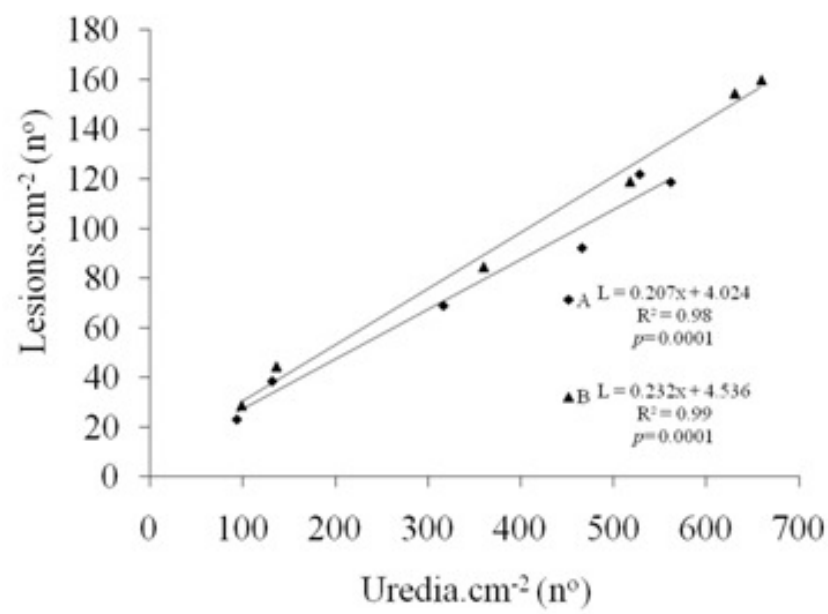

Figure 5. Relation between soybean rust uredia and lesion number.cm ${ }^{-2}$ in leaflets of soybean cultivar CD 214 RR. First experiment $(\boldsymbol{\Delta})$ and second experiment $(\diamond)$. University of Passo Fundo, 2008. 
Phakopsora pachyrhizi infection efficiency may be improved by PSM concentrations, as well by spore density. The spreader concentration of $240 \mu \mathrm{L} . \mathrm{L}^{-1}$ water resulted in the maximum disease intensity. Artificial inoculations with uredospore concentration of $5 \mathrm{x}$ $10 . \mathrm{mL}^{-1}$ water result in a disease intensity that enables rapid and accurate measurements. There was a correlation between the number of uredia and the number of lesions.

\section{REFERÊNCIASBIBLIOGRÁFICAS}

1. Alves, M. C.; Pozza, E. A.; Ferreira, J. B.; Araújo, D. V.; Costa, J. C. B.; Deuner, C. C.; Muniz, M. F. S.; Zambenedetti, E. B.; Machado, J. C. Intensidade da ferrugem asiática (Phakopsora pachyrhizi H. Sydow \& P. Sydow) da soja [Glycine max (L.) Merr.] nas cultivares Conquista, savana e suprema sob diferentes temperaturas e períodos de molhamento foliar. Summa Phytopathologica, v. 33, n. 3, p. 239-244, 2007.

2. Azevedo, L.A.S.; Juliatti, F.C.; Barreto, M. Resistência de genótipos de soja á Phakopsora pachyrhizi. Summa Phytopathologica, 33:252-257, 2007.

3. Bonato, E.R. Estresses em soja. Passo Fundo: Embrapa Trigo, 2000. 254p.

4. Carvalho, L.P., Carvalho, J.M.F.C., Lima, E.F. \& Cavalcante, F.B. Influência da concentração de esporos da patogenicidade de Colletotrichum gossypii South var. cephalosporioides A.S. Costa e avaliação da resistência de cultivares e linhagens de algodoeiro herbáceo à ramulose. Fitopatologia Brasileira 6:395-402. 1981.

5. Conab. Companhia Nacional de Abastecimento. Lavouras. Capturado em 23 de junho de 2008. Disponível on line: http:// www.conab.gov.br.

6. Fernandes, C.D., Del Peloso, M.C., Maffia, L.A., do Valle, F.X.R \& Zambolim, L. Influência da concentração de inóculo de Cercospora coffeicola e do período de molhamento foliar na intensidade da cercosporiose do cafeeiro. Fitopatologia Brasileira 16:39-43. 1991.

7. Godoy, C.V.; Canteri, M.G. Efeitos protetor, curativo e erradicante de fungicidas no controle da ferrugem da soja causada por
Phakopsora pachyrhizi, em casa de vegetação. Fitopatologia Brasileira, Brasília, v.29, p.97-101, 2004.

8. Godoy, C. V. Eficiência de fungicidas para o controle da ferrugem asiática da soja, Phakopsora pachyrhizi, na safra 2006/07. Resultados sumarizados dos ensaios em rede. Londrina: Embrapa Soja. Circular Técnica, n.42. 2007.

9. Henning, A.A \& Godoy, C.V. Situação da ferrugem da soja no Brasil e no mundo. In.: Zambolim, L. Manejo integrado da ferrugem asiática da soja. Viçosa: UFV, DFP, 2006. 140p.

10. Kohle, H.; Grossmann, K.; Jabs, T., Stierl, R.; Gerhard, M.; Kaiser, W.; Glaab, J.; Conrath, U.; Seehaus, K \& Herms, S. Physiological effects of the strobilurin fungicide F 500 on plants. p. 61-74 In: Fungicides and Antifungal Compounds, v.3. 2002.

11. Miles, M.R.; Levy, C.; Morel, W.; Mueller, T.; Steinlage, T.; Rij, N.; Frederick, R.D.; Hartmam, G.L. International fungicide efficacy trials for the management of soybean rust. Plant Disease. v.91: 1450-1458, 2007.

12. Navarini, L.; Dallagnol, L.J.; Balardin, R.S.; Moreira, M.T.; Meneghetti, R.C.; Madalosso, M.G. Controle químico da ferrugem asiática (Phakopsora pachyrhizi Sydow) na cultura da soja. Summa Phytopathologica, v.33, n.2, p.182-186, 2007.

13. Ritchie, S.; Hanway, J.J.; Thompson, H.E., 1982. How a Soybean Plant Develops. Ames, Iowa State University of Science and Technology, Coop. Ext. Serv. 20p. (Special Report, 53) - Adaptado por José Tadashi Yorinori, 1996, Embrapa Soja, Londrina.

14. Vidal, R. A.; Fleck, N. G. Absorção e translocação de defensivos agrícolas. In: Borges, L. D. Tecnologia de aplicação de defensivos agrícolas. Passo Fundo: Plantio Direto Eventos, 2006. p.57-70.

15. Sinclair, J. B.; Backman, P. A. Compendium of soybean Disease. 3 ed. Ed. St Paul, Minnesota: American Phytopathological Society, 1989, $106 \mathrm{p}$.

16. Sutton, J. C. Predictive value of weather variables in the epidemiology and management of foliar diseases. Fitopatologia Brasileira v.13, p. 305-312. 1988.

17. Toledo, J., Reis, E.M. \& Forcelini, C.A. Efeito do substrato na morfologia de conídios de Bipolaris sorokiniana e da densidade de inóculo na intensidade da mancha marrom em cevada. Fitopatologia Brasileira v. 29, p.005-010. 2004.

18. Yorinori, J. T., Godoy, C. V., Paiva, W. M., Frederick, R.D., Costamilan, L. N., Bertagnoli., P. F. \& Nunes, J. R. J. Evolução da ferrugem da soja (Phakopsora pachyrhizi) no Brasil, de 2001 a 2003. Fitopatologia brasileira 2003. (Suplemento). 